\title{
SUBJEKTIVITAS DALAM CERITA PERJALANAN NOVEL LUMBINI KARYA KRIS BUDIMAN
}

\author{
Novi Sri Purwaningsih \\ S2 Ilmu Sastra UGM \\ E-mail: novisri7@gmail.com
}

\begin{abstract}
Abstrak
Beberapa tahun terakhir ini banyak diterbitkan buku-buku yang memuat cerita perjalanan, baik perjalanan yang dilakukan di Indonesia, maupun luar negeri. Ada yang diterbitkan dalam bentuk novel, memoar, buku panduan perjalanan, bahkan puisi atau cerpen. Tulisan ini diangkat sebagai bentuk sambutan positif terhadap fenomena tersebut. Novel Lumbini karya Kris Budiman menjadi salah satu cerita perjalanan yang bercerita tentang perjalanan Ratna dan Niko di Nepal. Dengan menggunakan sudut pandang yang berubah-ubah, tulisan ini bertujuan menggambarkan subjektivitas dalam cerita perjalanan novel Lumbini. Untuk menganalisis data dan kasus, penulis menggunakan teori dan konsep travel writing yang dikemukakan oleh Carl Thompson dalam buku yang berjudul Travel Writing (2011). Selanjutnya, simpulan yang dapat ditarik dari analisis ini adalah bahwa subjek "aku" dalam novel bukanlah subjek yang mandiri atau bebas karena pada saat yang lain bersubstitusi dengan "kami". Selama perjalanan, subjek "aku" melakukan interaksi terhadap objek-objek yang digambarkannya, sehingga subjek juga disebut subjek (diri) romantik. Menurut Thompson, diri romantik nampaknya lebih terbuka daripada diri pencerahan.
\end{abstract}

Kata Kunci: subjektivitas, travel writing, subjek romantik.

\begin{abstract}
In the recent years, there are numerous books containing travel writing, both in Indonesia and abroad, have been published. The books can be a novel, memoir, travelogue, poetry, and short story. One of the novels containing travel writing is Lumbini written by Kris Budiman. It is about Ratna and Niko who travel to Nepal. Told in many points of view, this novel shows its subjectivities. In order to reveal this, the researcher will apply the concept of travel writing by Carl Thompson. Through the analysis, it is found that subject "I" in this novel is not a dependent subject because it, sometimes, is substituated with "we". Besides, subject "T" also interact with other object. Thus, the subject can be classified as an "romantic self". According to Thompson, it seemingly more open than Enlightenment self.
\end{abstract}

Keywords: subjectivity, travel writing, romantic subject.

\section{Pendahuluan}

Bagi Barat, Timur adalah sebuah tempat yang jauh, penuh dengan romansa, feminin, dan eksotis (meminjam istilah Said). Sejak kedatangan Portugis ke Indonesia kemudian disusul Spanyol dan Belanda yang bertahan hingga beratus-ratus tahun membuktikan bahwa Timur adalah wilayah yang memberikan daya tarik tersendiri bagi bangsa Barat. Ini terlepas dari apa tujuan negara-negara tersebut mendatangi Indonesia dan negara-negara Asia lainnya. Banyak buku sejarah yang menyatakan bahwa tujuan awal kedatangan bangsa Eropa ke Indonesia untuk urusan perdagangan rempahrempah, kemudian berlanjut menjadi sebuah kolonisasi.
Nieuwenhuys (via Faruk, 2007: 162) menuturkan bahwa rangkaian peristiwa tersebut dirangsang dan didahului oleh terbitnya serangkaian cerita perjalanan. Cerita perjalanan tersebut mengandung gambaran mengenai pengalaman orang-orang Eropa dalam mengarungi lautan, menemukan wilayahwialayah asing, dan mengandung semacam peta yang rinci mengenai lautan dan wilayahwilayah asing tersebut. Cerita-cerita tersebut memberikan dorongan mental sekaligus panduan teknis bagi orang-orang di atas untuk akhirnya melakukan perjalanan. Sebuah perjalanan yang berakhir pada pendudukan terhadap wilayah baru dan asing, salah satunya ialah Indonesia. 
Selain Indonesia, beberapa negara di Benua Asia juga tak lepas dari kolonisasi bangsa-bangsa Eropa. Indonesia pernah mengalami penjajahan oleh beberapa bangsa Eropa seperti Portugis, Spanyol, Inggris, dan Belanda. Tidak hanya di Indonesia, Inggris juga pernah menduduki negara Asia lainnya seperti Malaysia, India, dan Nepal. Selanjutnya, membahas Nepal seperti melakukan petualangan di mana Buddha Gotama pernah dilahirkan di sebuah situs yang dilindungi. Situs tersebut ialah Taman Suci Lumbini. Sebenarnya masih banyak lagi situs-situs suci lainnya di Nepal, tetapi situs Lumbini lah yang terkenal. Ada banyak hal menarik yang dapat diceritakan dari negara ini selain situs-situs bersejarahnya. Nepal merupakan Kerajaan Hindu satusatunya di dunia setidaknya hingga tahun 2006 lalu. Setelah bertahan selama 250 tahun lamanya, akhirnya Nepal mengganti sistem pemerintahannya dan menyatakan diri sebagai negara sekuler pada tanggal 28 Mei 2008. Nepal juga memiliki bentang alam yang indah terutama karena berada di deretan Pegunungan Himalaya (via welcomenepal.com).

Bagi umat Buddha, situs Taman Lumbini di Nepal merupakan tempat yang wajib dikunjungi karena di tempat inilah Sang Buddha Gautama lahir. Menurut salah satu kitabnya, yaitu Parinibbana Sutta, didentifikasikan adanya empat bentuk ziarah dimana umat Budha akan memberikan penghormatan setelah kepergian Budha dari dunia. Keempat bentuk ziarah tersebut ialah tempat kelahiran Buddha, pencerahannya, khotbah pertamanya, dan kematiannya (via id.thecircumference. org). Artinya, dengan berziarah ke Taman Lumbini, umat Budha melakukan salah satu penghormatan setelah kepergian Sang Budha. Hal ini serupa dengan salah satu rukun Islam yang mewajibkan umat Islam yang mampu secara lahir dan batin untuk melaksanakan ibadah haji ke Mekkah. Dalam hal ini, ibadah haji merupakan kegiatan ziarah ke makam Nabi Ibrahim SAW. Perjalanan ziarah bisa dilakukan secara pribadi maupun rombongan seperti yang dilakukan umat beragama di masing-masing hari besar agamanya. Kegiatan ziarah sendiri menurut Thompson merupakan hal yang paling umum dalam dunia wisata abad pertengahan.

Membicarakan Taman Lumbini sebagai salah satu tempat tujuan ziarah bagi umat Budha, novel karya Kris Budiman yang berjudul Lumbini bercerita mengenai perjalanan dua orang Warga Negara Indonesia yang bertemu di Nepal. Ratna adalah seorang perempuan yang sengaja berkunjung ke Nepal murni untuk berwisata. Ia tinggal dan bekerja di Jakarta, di perusahaan ayahnya. Sewaktu dirinya ditugasi ke Singapura dan sudah menyelesaikan tugasnya, Ratna langsung mengambil penerbangan ke New Delhi tanpa memberitahu siapa pun. Begitulah alasan Ratna berada di Nepal, yakni ingin sementara waktu mengasingkan diri dari kesibukannya di Jakarta dan menikmati keindahan di kaki Pegunungan Himalaya. Selanjutnya Niko atau Nikaya Suttomo ialah seorang laki-laki lulusan Arkeologi UGM tahun 1994 dan sedang terlibat sebuah proyek bernama Bhaktapur Research Program yang diselenggarakan oleh Departemen Seni Rupa dan Desain, Universitas Kathmandu.

Perkenalan yang terjadi antara keduanya menjadi awal perjalanan 'eksotis' dalam mengunjungi tempat-tempat yang baru bagi Ratna. Kepergian Ratna ke Nepal menjadikannya seseorang yang baru dengan melakukan hal-hal yang baru pula. Melakukan meditasi, mengunjungi situs-situs kuno, mengunjungi perpustakaan, dan pergi ke Taman Lumbini bersama Niko. Di tempat inilah Ratna mengalami perjalanan batin yang tidak dapat dialami oleh setiap orang. Dalam konteks cerita perjalanan, novel ini mengungkapkan perjalanan "aku" mengunjungi tempat-tempat yang tidak biasa di Nepal.

Melalui novel Lumbini karya Kris Budiman akan dicari diri atau subjek seperti apa yang ada, dan perjalanan penemuan diri seperti apa yang diceritakan dalam novel ini. Dalam kisah-kisah 
perjalanan kolonial di masa lalu, perjalanan merupakan penemuan diri, pembangunan subjek dan posisinya di dalam lingkungan sekitar. Oleh karena itu, perjalanan bukanlah sekedar gerakan dari satu lokasi geografis ke lokasi geografis yang lain, tetapi juga peralihan dari usia remaja ke usia dewasa. Perjalanan juga menjadi peralihan dari satu kepribadian ke kepribadian yang lain, satu kecenderungan mental ke kecenderungan mental yang lain. Karena perjalanan itu sekaligus merupakan perjalanan untuk penemuan diri, mental, ataupun psikologis, tidak menjadi penting gambaran lokasi-lokasi yang dikunjungi(nya). Hal yang terpenting adalah penemuan diri subjek itu sendiri, bahkan diri (subjek) dapat ditemukan sebelum perjalanan itu sampai ke tujuan (Faruk, 2014).

Selanjutnya, "aku" dalam novel tipis karya Kris Budiman ini digambarkan sebagai diri yang mencari ketenangan, menghindar sejenak dari rutinitasnya sehari-hari. Dapat dikatakan pula bahwa "aku" melakukan perjalanan spiritual selama berada di kota Kathmandu, Nepal. Namun hal itu tidak disadarinya hingga pertemuan 'batin' dengan seorang bhikeku saat memandang arca Mayadevi di Taman Lumbini. Ratu Mayadevi ialah ibu dari Pangeran Siddhartha atau Sang Buddha. "Tepat di sebelah selatan Kuli Mayadevi terbentang sebuah kolam suci. Pemandian yang sesunggubnya tidak terlampau luas ini lebih dikenal oleh penduduk setempat dengan nama Puskarni. Tidak sedikit yang meyakini bahwa Ratu Maya Devi mandi menyucikan diri sebelum melabirkan putranya" (Budiman, 2006: 10).

Lumbini sebagai judul sebuah novel ditulis menyerupai huruf devanagari dengan bentuk novel yang tipis dan kecil merupakan hal yang menarik,unik, namun tetap eksentrik. Memang novel ini sangatlah tipis untuk ukuran sebuah novel, tetapi isinya begitu mendalam dan luas. Pengalaman batin "aku" di sebuah tempat yang asing, ajaran-ajaran Budha yang diperoleh "aku" dari mengikuti meditasi beberapa kali saja menjadikan "aku” sebagai diri yang baru.
Selanjutnya, akan dibahas lebih mendalam lagi "aku" adalah diri atau subjek yang seperti apa. Penulis cerita perjalanan sendiri biasanya mengungkapkan dirinya atau asumsi subjektifnya melalui tokoh-tokoh dalam cerita. Untuk menjawab pertanyaan di atas digunakan teori poskolonial Thompson terutama dalam bukunya Travel Writing (2011).

Sebagaimana diketahui, pengaruh bangsa penjajahan tidak begitu saja dapat terhapus dari pandangan, sikap, dan perilaku masyarakat yang pernah terjajah. Sistem pemerintahan yang diterapkan oleh pemerintah kolonial Belanda pada gilirannya membentuk sebuah tata politik, ekonomi, sosial, bahkan kultural yang biasa disebut "dualistik". Kondisi semacam ini sengaja diciptakan oleh penjajah, sehingga apa pun yang menjadi pilihan masyarakat terjajah justru merupakan praktik kepatuhan terhadap kekuasaantersebut. Posisi mendua juga terlihat dalam karya sastra berupa novel dengan menciptakan karakteristik subjek yang berbeda. Subjek yang pertama diciptakan untuk patuh pada kekuatan eksternal, sedangkan subjek kedua ialah subjek yang mandiri dari kekuatan tersebut (Faruk, 2007: 370).

Kondisi yang mendua tersebut juga berpengaruh terhadap karya sastra Indonesia yang dihasilkan, salah satunya dalam cerita perjalanan. Cerita perjalanan sebagai salah satu produk sastra sudah banyak ditulis dan dikonsumsi oleh orang-orang Belanda sejak abad XVI. Cerita-cerita perjalanan tersebut pada gilirannya memberikan dorongan bagi bangsa Belanda untuk berlayar menuju, mencapai, dan akhirnya menguasai wilayah tersebut. Cerita perjalanan yang selanjutnya ditulis oleh penulis-penulis dari wilayah yang pernah dikoloni berada pada posisi yang mendua pula. Meskipun demikian, cerita perjalanan tersebut telah menciptakan suara baru bagi representasi kebudayaan bangsa lain, setidaknya ini yang dinyatakan Thompson dalam bukunya Travel Writing (2011).

Said (2010: 176) menuturkan bahwa dunia 
Timur selama ini dianggap sebagai kawasan yang jauh berbeda dengan tanah-tanah Islam. Literatur-literatur penjelajahan, utopia-utopia imajiner, pelayaran-pelayaran, dan laporanlaporan ilmiah yang ditulis orang-orang Eropa semakin memperluas dan memperdalam pengetahuan manusia tentang Timur. Hal ini juga megukuhkan posisi Eropa di poros yang terhormat sebagai pengamat utama. Bahkan ketika Eropa bergerak keluar dari kawasannya sendiri, kesadaran akan kekuatan budaya yang dimilikinya menjadi semakin kuat. Dari kisahkisah penjelajah inilah daerah jajahan dibentuk dan perspektif etnosentris dikendalikan.

Selain itu, dalam menelaah Timur, ziarah merupakan aktivitas yang dapat dilakukan oleh orang-orang Eropa. Mereka tak hanya cukup mengkaji Timur dari teks-teks imajinatif. Lebih dari itu, mereka harus mengunjunginya, memotretnya, dan jika perlu mengurusnya secara konsisten. Dari peziarahan ini mereka menulis pengalaman-pengalaman pribadi mereka selama berada di Timur. Dan seperti yang sudah diketahui, tulisan pribadi itu nantinya akan menjadi sejenis tulisan ilmiah yang bisa dikutip secara resmi oleh mereka yang berkepentingan (Said, 2010: 257).

Ketika memerhatikan, misalnya, tentaratentara, para konsulat, pedagang-pedagang, dan ekspedisi-ekspedisi arkeologis yang dilakukan Barat terhadap Timur, akan diketahui bahwa ternyata jumlah wisatawan dari Timur Islam ke Eropa antara tahun 1800 dan 1900 relatif sangat kecil, apalagi jumlah ini dibandingkan dengan jumlah wisatawan Barat yang berziarah ke Timur. Orang-orang Timur yang berziarah ke Barat pada umumnya bertujuan untuk belajar dari dan mengagumi suatu budaya yang menurut mereka tampak maju. Sebaliknya, orang-orang Barat yang berziarah ke Timur memiliki tujuan yang berbeda. Mereka pergi ke Timur dengan tujuan menjadikan Timur sebagai objek kajian untuk nantinya dipersembahkan kepada para pembaca di tanah air mereka. Tidak berhenti di sini saja, jika melihat kenyataan akademis antara kedua kebudayaan tersebut, akan ditemukan dua poros yang berbeda satu sama lain (Said, 2010: 314).

Melanjutkan penjelasan di atas, maka travel writing sebagai salah satu budaya kolonial yang masih diproduksi dan dikonsumsi hingga saat ini diharapkan memberikan wawasan yang baru. Tidak melulu mengenai eksplorasi terhadap Timur, tetapi juga sebaliknya. Thompson (2011: 10) mendefinisikan "If all travel involves an encounter between self and other that is brought about by movement through space, all travel writing is at some level a record or product of this encounter, and of the negotiation between similarity and difference that it entailed." Jadi, travel writingmerupakan catatan yang di dalamnya melibatkan pertemuan antara self dan other juga negosiasi-negosiasi atas perbedaan atau persamaan yang dimiliki oleh self dan other itu sendiri.

Dalam travel writing atau cerita perjalanan juga terdapat beberapa aspek penting yang dijelaskan melalui kutipan di bawah ini.

"Consequently, all travel writing has a two-fold
aspect.It is most obviously, of course, a report
on the wider world, an account of an unfamiliar
people orplace. Yet it is also revelatory to a greater
or lesser degree of the traveller who produced that
report, and of his or her values, preoccupations
and assumptions. And, by extension, it also
reveals something of the culture from which that
writer emerged, and/ or the culture for which their
text is intended" (Thompson, 2011: 10).

Aspek-aspek penting tersebut antara lain bahwa cerita perjalanan merupakan semacam laporan tentang dunia yang luas, tentang manusia atau tempat-tempat yang tidak biasa. Cerita perjalanan mengungkapkan nilai-nilai yang dipegang oleh penulis atau asumsi-asumsi penulisnya. Selain itu, juga mengungkapkan budaya asal penulisnya atau budaya daerah yang diceritakan. Tak hanya aspek-aspek di atas, dalam cerita perjalanan juga akan ditemui beberapa jenis diri, "self" atau subjek dengan karakteristiknya masing-masing. 
"As defined by Maxine Feifer (1986), the 'post-tourist' is someone who knows that notions of getting off the beaten track, and of being a 'traveller' rather than a 'tourist', are usually self-deluding fantasies and an illusion frequently manufactured by the tourist industry it self. The posttouristic travel writer will accordinghy often reject and mock the rhetoric of authenticity that has been so conspicuous in travel writing in the past. Typically they will be far less disdainful of the alleged inauthenticity of mainstream tourist activities and, even when they engage in very different activities, they are often prepared to admit that these are just a variant form of tourism, rather than a radically different and superior type of travel" (Thompson, 2011: 126).

Menurut pendapat Maxine Feifer (via Thompson, 2011: 126), diri 'post-turis' mengejek 'traveller' karena sebenarnya seorang traveller merupakan bagian dari perjalanan turistik atau industri wisata. Terdapat perbedaan antara turis atau pelancong dengan traveler, namun pada dasarnya keduanya berada dalam industri wisata. Sebelum melakukan perjalanan seorang pelancong sudah memiliki rencana yang rapi dan biasanya sudah diatur oleh biro perjalanan. Dengan demikian, perjalanan yang diikutinya merupakan perjalanan wisata yang aman dan terencana, sedangkan traveller biasanya menyukai perjalanan eksploratif dan tidak terikat oleh biro perjalanan. Melakukan perjalanan dengan bersama-sama atau ditemani orang lain merupakan perjalanan yang aman, sekalipun dirinya mengaku sebagai traveller. Sebagai contoh sebuah kegiatan pendakian terlihat begitu menantang dan membahayakan, padahal kegiatan itu umumnya dilakukan secara berkelompok dan di antara kelompoknya pasti ada satu atau dua orang yang berposisi sebagai pemandu pendakian. Hal inilah yang pada akhirnya menjadi alasan bagi diri post-turis untuk mengejek traveller.

Selain diri 'post-turis', Thompson juga menjelaskan tentang diri 'romantik' atau diri yang terlibat, artinya dalam perjalanannya subjek tidak hanya mengamati, tetapi juga bereaksi terhadap peristiwa di sekitarnya. Diri atau subjek yang 'romantik' suka mencari situasi yang dapat membangkitkan perasaan dan memiliki nilai spiritual yang kuat. Diri romantik lebih terbuka dan tidak saja hanya mencatat mengenai perjalanan literal, tetapi juga perjalanan batin seperti pematangan dan penemuan diri. Subjek atau diri romantik juga dapat dikatakan sebagai subjek yang longgar.

Jenis diri atau subjek selanjutnya ialah diri 'pencerahan' atau diri yang utuh, tidak mengalami perubahan. Diri 'pencerahan' merupakan biner oposition dari diri 'romantik'. Diri 'pencerahan' selalu memprioritaskan fakta dan melakukan penyelidikan secara empiris dalam perjalanannya. Diri 'pencerahan' merupakan pengamat dan subjek yang kaku. Untuk itulah diri 'pencerahan' dikatakan sebagai biner oposition dari diri 'romantik'.

Di era ini, travel writing menyajikan perjalanan sebagai ritual penting dari perjalanan dan sebagai proses realisasi diri. Dalam travel writingmemang sering digambarkan semacam ziarah atau pencarian, karena ini adalah dua jenis wisata yang membawa pembaharuan diri. Sebagai contoh,ziarah dan pencarian merupakan perjalanan yang sering dianggap sebagai ritus perjalanan penting pada periode sebelum akhir abad kedelapan belas. Sehubungan dengan hal ini, diri 'romantik' lebih banyak memiliki peluang mengalami an epiphanic insight into him or herself. Semua penjelasan ini terutama dari hasil pembacaan pada Bab 5 Revealing The Self (Thompson, 2011).

\section{Subjek "Aku” dalam Perjalanan}

Secara umum, pengarang menggunakan sudut pandang orang pertama, "aku", untuk merepresentasikan kehidupan alamiah, sosial, dan kultural yang dialami si tokoh cerita. Akan tetapi, sudut pandang orang pertama tunggal dalam novel Lumbini sering berganti menjadi "kami" (menggantikan "aku" Ratna dan "dia" Niko). Dalam dialog yang dituturkan oleh "aku", narator sesekali menyapa pembaca, sehingga mengesankan adanya hubungan yang 
dekat antara narator dengan pembaca. Seperti pernah dinyatakan Faruk (2007: 185) bahwa sudut pandang orang pertama tunggal, "aku", merepresentasikan diri sebagai manusia dalam keadaannya yang paling konkret, sedangkan "kami" merepresentasikan manusia dalam keadaannya yang kolektif, abstrak, dan terbagi. Nukilan-nukilan cerita di bawah ini akan menunjukkan perubahan sudut pandang yang terjadi.

"India adalah salah satu negeri dongeng favoritku di masa kecil dulu. Aku selalu membayangkan kehidupan dewa-dewi, perempuan-perempuan cantik berkulit tembaga yang sarat aksesori gemerincing, para fakir ajaib, ritual-ritual magis, kuilkuil, juga Ramayana dan Mahabharata, kalau mendengar nama negeri itu disebut orang. Salah satu mimpi konyolku di masa remaja dulu adalah untuk suatu ketika bersekolah di India, mungkin untuk mempelajari kesenian, filsafat, atau mungkin juga ilmu sihir, nujum, atau yang sebangsanya" (Budiman, 2006: 25).

"Maaf, cerita ini agak terganggu oleh interupsi konyol. Akan kulanjutkan tentang Bhaktapur Research Program yang lagi diikuti oleh Niko. Program ini pada dasarnya merupakan sebuah proyek penelitian dan pendokumentasian berskala raksasa yang diselenggarakan oleh Universitas Kathmandu bekerja sama dengan Pemerintah Kotamadya serta didukung oleh sejumlah institusi berwibawa dari luar negeri, antara lain Obio State University dan The British Museum of London, atas berbagai arca batu dan perunggu yang tersebar di Bhaktapur dan wilayah-wilayah sekitarnya..." (Budiman, 2006: 36).

"Kini menjadi jelas mengapa kami sama sekali tidak pernah mendapat kesempatan untuk bertemu selama tahun-tahun kuliah di UGM. Ibaratnya, kami mendiami dua sisi yang berbeda dari satu koin yang sama. Kegiatanku di kampus tidak pernah jauh ke mana-mana selain di tingkat jurusan dan fakultas, pulang ke tempat kos, belajar, membuat maket, sesekali naik gunung, dan selebihnya keluyuran bersama Afkar. Dia menempel terus di sisiku seperti seorang bodyguard atau, bagiku lebih tepat, seekor kucing. Sementara Niko, dalam kesanku, adalah tipikal aktivis yang tidak pernah pulang ke rumah, bahkan makan, tidur, dan mandi pun dilakoninya di kampus. (Apakah penampilan kamu dulu sudah sehigienis sekarang, Nik? Atau, apakah kamu sewaktu kuliah itu tergolong sebagai mahasiswa kumuh yang jarang menyentuh sabun? Hihi, jangan tersinggung, aku cuma lagi berusaha membayangkan dirimu dengan lebih konkret....")

Konon, pernah sekali waktu Niko terpaksa melewati masa liburan semester yang bertepatan dengan Hari Raya tanpa pulang mudik. Gelanggang Mahasiswa sepi nyenyet. Kantin yang biasanya riuhrendah, tutup. Rumah kos tanpa penghuni kecuali bapak dan ibu kos. Dia bertahan hidup nyaris hanya dengan mengandalkan mi dan nasi goreng instan selama kuranglebih lima hari lima malam...." (Budiman, 2006: 40-41).

Nukilan yang pertama menunjukkan penggunaan sudut pandang orang pertama tunggal atau "aku" dalam novel Lumbini. Nukilan kedua menunjukkan bagaimana narator berinteraksi dengan pembaca, sehingga terlihat hubungan yang dekat antara narator dan pembaca. Narator seakan berbicara langsung dan meminta maaf kepada pembaca, sehingga hal ini seperti terjadi pada sastra lisan bagaimana seorang penutur berkomunikasi dengan para pendengarnya. Nukilan selanjutnya menunjukkan perubahan sudut pandang dari orang pertama tunggal (akuan) menjadi orang pertama jamak (kami), bahkan menjadi orang ketiga tunggal (dia). Dengan posisi yang demikian, tampak bahwa "aku" bukanlah pribadi yang mandiri karena selain diri "aku" juga terdapat "dia", sehingga menjadi "kami".

Memang pada awalnya "aku" (Ratna) berniat melakukan perjalanan seorang diri di Nepal, tetapi setelah bertemu dengan "dia" (Niko) Ratna tidak dapat terlepas dari Niko, bahkan seperti bergantung pada Niko. Ratna merasa senang karena menemukan orang 
senegaranya di negeri lain, bahkan pernah satu almamater sewaktu kuliah dulu. Dengan demikian, subjek "aku" yang dibangun dalam cerita ini bukanlah subjek yang mandiri. Latar belakang Ratna yang dijelaskannya sendiri melalui "aku" menegaskan bahwa dirinya berasal dari keluarga kaya.

Sejak kecil dirinya terbiasa melakukan liburan dan perjalanan ke luar negeri, terutama di musim libur. "Aku" memiliki kehidupan yang monoton dan keinginannya dengan mudah dapat dipenuhi oleh orangtuanya. "Aku" sebagai individu yang suka bertualang lebih menyukai petualangan dalam dunia fantasi, yaitu petualangan imajiner. Imajinasi tidak mengenal batas, dan ini membuat kebosanan hidupnya sedikit terobati. Petualangan imajiner itu dipengaruhi oleh tokoh-tokoh antah berantah macam Sinbad, Oki dan Nirmala, serta Indiana Jones dalam film-film seperti Raider of the Lost Ark, Temple of the Doom, dan Last Crusade sebagai film produk negara-negara Barat.

Di lingkungan keluarganya, “aku” (Ratna) tidak bisa bebas menentukan keinginannya sendiri karena hidupnya selalu berada di bawah bayang-bayang orangtuanya. Hidupnya benar-benar diatur oleh orangtuanya, hingga dengan tanpa berpikir panjang memutuskan untuk kabur ke Nepal sementara waktu. Novel ini mengisahkan sebuah perjalanan di masa modern. Sebuah perjalanan yang tidak lagi ditempuh dengan kapal laut, namun pesawat yang nyaman dan tidak membutuhkan waktu berhari-hari untuk mencapai tempat tujuan. Tentu saja tidak ada kesulitan yang ditemui "aku" dalam perjalanannya. Tidak ada ketakutan atau kekhawatiran yang dirasakan Ratna selama berada di Nepal.

Seperti cerita-cerita perjalanan modern lainnya, tokoh-tokoh yang melakukan perjalanan di dalamnya sudah dibekali informasi mengenai tempat-tempat yang akan ditujunya. Modal pengetahuan tentang tempat atau kebudayaan yang baru tersebut memudahkan subjek ketika berada di sana. Semacam buku panduan perjalanan, di dalam novel ini terdapat daftar menu makanan dan minuman yang dijual di kantin Student Hostel milik Universitas Kathmandu lengkap dengan harganya dalam nilai mata uang rupee. Tidak jauh dari Student Hostel terdapat toko buku sekaligus perpustakaan yang bernama The Pilgrim's Book Store. Buku-buku yang dijual berupa bukubuku keagamaan, spiritualitas, sejarah, dan kebudayaan Nepal. Selain buku, pernak-pernik cinderamata, barang kerajinan, berbagai macam kebutuhan ritual dan piranti upacara seperti arca-arca Buddha dan dewa-dewi Hindu, dupa, kristal, dan lain-lain juga dijual di toko ini. Ketika "aku" melihat dupa, dupa tersebut punya merek yang tidak asing baginya. Merek dupa tersebut merupakan judul puisi karya Rabindranath Tagore sastrawan terkenal dari India yang pernah diterjemahkan oleh Amal Hamzah. Karya tersebut pernah dibacanya sewaktu masih SMA. Gitanjali: A perfume of poems menjadi sebuah merek komoditas made in Bangalore, India.

Bagaimana subjek mengetahui hal-hal tersebut kalau bukan karena pendidikan modern yang diterimanya. Di dalam pikirannya sudah tersedia banyak informasi tentang berbagai hal, bahkan tentang suatu tempat asing yang belum pernah dikunjunginya sekalipun. Artinya, subjek "aku" bukan subjek yang bebas karena pikirannya sudah terikat oleh pengetahuanpengetahuan yang pernah ditanamkan oleh kolonial. Subjek menyelami pikirannya sendiri karena di dalam otaknya sudah tersedia berbagai pengetahuan.

Untuk itu, kutipan di bawah ini menunjukkan respon yang diberikan "aku" ketika dirinya sampai di Taman Lumbini.

"Lumbini yang kubayangkan sebelumnya adalah sebuah taman bunga yang asri, tenang, dan damai. Sebuah Taman Sari yang sudah sepatutnya menjadi tempat kelahiran seorang Pangeran Siddharta Gotama. Demikianlah imajinasiku bila membaca atau mendengar cerita 
tentang Taman Lumbini. Aku tetap yakin bahwa begitulah memang kenyataannya, setidaknya dulu, dua ribu lima ratus tahun sebelum hari ini".

"Kini Lumbini bukan hanya sebuah kompleks situs arkeologis yang besar dan dilindungi, melainkan juga sebuah lokasi wisata ziarah yang wajib kunjung bagi siapa saja yang mengambil paket Buddhist Pilgrimage Tour yang banyak ditawarkan di biro-biro wisata di Kathmandu atau New Delhi (mirip seperti Paket Wisata Ziarah Lourdes atau Paket Umroh di Indonesia). Lumbini is the Mecca of every Buddhist, 'Mekah'-nya kaum Buddhis, demikian setiap brosur berbunyi kompak dalam mempromosikannya. Kompleks ini dibelah oleh sebuah jalur utama yang membujur dari utara ke selatan, melewati Eternal Peace Flame, lalu sampai di sebuah area yang dikenal sebagai Taman Suci, tempat Kuil Mayadevi, Kolam Suci, dan Pilar Ashoka berada. Kecuali itu, di sepanjang jalur utama masih terdapat Lumbini Museum, Lumbini International Research Institute, Sri Lanka Pilgrim Rest House, serta sekian vihara dan stupa yang telah didirikan oleh para peziarah dari berbagai negara Buddhis".

Konon, taman ini merupakan salah satu dari empat tanah suci yang telah ditunjukkan sendiri oleh Sang Buddha, di samping Bodh Gaya (tempat Siddharta menjadi Buddha, mencapai Penerangan Sempurna); Taman Rusa di Sarnath, di dekat Varanasi (tempat khotbahnya yang pertama kali, yang lebih dikenal sebagai 'Memutar Roda Dhamma'); serta Kushinagar (tempat Gotama Buddha mencapai parinibbana). Semuanya terletak di, menjadi wilayah kekuasaan dari, negara India. Satu-satunya yang dimiliki oleh Nepal hanyalah Taman Lumbini. Itu pun secara geografis lokasinya persis di perbatasan. Keadaan ini tentu mengandung konflik potensial, sedikitbanyak bisa berdampak dalam hubungan politis di antara kedua negara tetangga tersebut.

Kalau kupikir-pikir, kepentingan bisnis wisata, yang tak lain dan tak bukan adalah the quest for tourist dollar yang berbungkus nasionalisme superfisial, telah secara telak mengalahkan dimensi kultural dan spiritual, bahkan kepentingan ilmiah sekalipun” (Budiman, 2006: 83-85).

Sebelum subjek sampai atau berkunjung ke Taman Lumbini, subjek sudah memiliki gudang pengetahuan dari literatur-literatur yang dibacanya mengenai tempat tersebut. Akibatnya, ketika subjek melihat sendiri keadaan tempat tersebut dan ternyata tidak sesuai dengan bayangannya selama ini, maka subjek memiliki pikiran seperti di atas. Subjek tidak hanya menjadi traveller pengamat, tapi juga bereaksi atas apa yang dilihat di sekitarnya.

"Tiba-tiba kulihat seorang bbikk,ku mendatangi. Belum terhitung tua dia. Kedua matanya yang teduh, berkacamata bening, terarah dalam jarak pandang beberapa meter ke depan, menatap tanah. Dia melangkah pelan, seolah-olah dalam mode slow motion, ke arahku.

"Ratna!" panggilnya. Matanya tetap menatap tanah.

Aku menghampiri dan mengikuti di belakangnya tanpa berucap sepatah kata pun. Bhikkbu itu meneruskan langkah tanpa berpaling. Lambaaan sekali, menuju ke sebuah vihara sunyi.

"Mari....."

Semerbak wangi dupa. Harumnya! Sebuah patung berwarna kuning keemasan, Buddharupam, tersenyum damai. Menjulang dalam keagungan. Kulepaskan alas kakiku. Masuk, lalu duduk bertumpu lutut. Dia di depan; aku beberapa meter di belakangnya" (Budiman, 2006: 88).

"Aku" (subjek) mengalami pertemuan dengan seorang bhikkhutepat ketika sedang berada di depan relief Ratu Mayadevi dan memandangnya. Hal ini menjadi sebuah pengalaman spiritual yang tak pernah terpikirkan bagi "aku”. Ziarahnya ke tempat tersebut memberinya penglihatan masa lalu tentang kelahiran Bayi Suci yang dilahirkan Ratu Mayadevi. Dari peristiwa tersebut, "aku" juga mendapat pelajaran dari bhikekhu tersebut bahwa "pikiran yang terpusat jikalau dilakukan terus-menerus dengan sabar, akan membuahkan hasil yang sebelumnya tampak 
musykil. Tetes-tetes air yang lemah dan lembut sanggup melubangi bongkah batu yang keras". Peristiwa yang dialami "aku" semacam vision, dan memperoleh an epiphanic insight into berself. Untuk kedua kalinya“aku" juga mengalami hal yang sama, tetapi lokasinya berbeda, yakni di Candi Mendut, Magelang. Hal ini memang sudah direncanakan karena saat pertemuan pertamanya dengan bhikkku itu "aku" disuruh datang ke Candi Mendut, Magelang pada saat Perayaan Hari Raya Waisak.

"Pohon bodhi yang terkesan wingit itu menaungi sebuah arca shramana, pertapa, yang kurus kering berbalut lumut. Agaknya arca ini hendak menggambarkan betapa ekstrim namun sia-sianya upaya penyiksaan diri yang pernah ditempuh Sang Pertapa Gotama, sebelum akhirnya berhasil menemukan Jalan Tengah dan mencapai Penerangan Sempurna. Suasana di bawah pohon terasa senyap dan lembap. Dengan hati-hati aku mendekati. Di bawah telapak kakinya kulihat sebuah benda kecil berwarna biru langit: sepotong batu pirus yang secara alamiah terbentuk sebagai Buddharupam! Mirip dengan yang pernah kuberikan kepada Niko. Perlahan-lahan batu itu kuraih dan kugenggam.

"Semoga semua makhluk berbahagia. Sadhu. Sadhu. Sadhu," sayup terdengar suara bhikkkhu di belakangku.

Segera kubalikkan tubuh, "Bhante,..."

Namun, aku tertegun. Darahku berdesir lebih deras. Bhikkhu itu sudah tidak berada di tempatnya. Raib.

"Bahkan belum sempat saya bertanya ...." Vihara begitu senggang.

Ketika kuangkat kaki,

Tubuh ini serasa melayang" (Budiman, 2006: 114).

Pertemuan antara "aku" dengan bbikkhu menyisakan pertanyaan, namun demikian diri "aku" merasa lebih tenang dan merasa menjadi diri yang lebih matang. Pada awalnya, "aku" datang ke Nepal murni untuk sekadar jalan-jalan. Setelah bertemu dengan Niko, seorang arkeolog yang sedang menjalankan proyek penelitian terhadap situs-situs bersejarah di Nepal, maka "aku" dengan senang hati turut serta dalam segala kegiatan yang dilakukan Niko sebagai arkeologis. Selain mengunjungi tempat-tempat bersejarah, "aku" juga mengalami perjalanan spiritual yang tidak pernah dibayangkan sebelumnya.

Pada penjelasan awal disebutkan bahwa dalam novel ini terjadi perubahan sudut pandang dari orang pertama tunggal menjadi orang pertama jamak, bahkan terkadang berlaku sebagai diaan serba tahu meskipun tidak terlalu intens. Artinya, "aku" dalam novel ini bukan pribadi atau subjek yang bebas karena terikat oleh lingkungan sekitarnya. "Aku" bersubtitusi menjadi "kami", sehingga di dalam "kami" juga ada "dia" dan "mereka". "Kami" sama dengan "kita" yakni sama-sama subjek kolektif yang menunjuk kepada orang pertama jamak. Menurut Faruk (2007: 199-200) "kita"merupakan sesuatu yang sudah meliputi segalanya, tidak ada sesuatu di luar kita. Dengan demikian, "kita" merupakan sebuah kesatuan yang sudah penuh, sudah lengkap di dalam dirinya, sesuatu yang final. Kepenuhan ini membuat "kita" bersifat tetap, abadi, tidak mengenal perubahan dan perkembangan karena ia tidak mempunyai sesuatu yang lain yang dapat menjadi tandingan dan tantangan baginya. Kalaupun ada masalah, bukanlah pertentangan antara subjek dan objek, melainkan persoalan mengenai usaha diri untuk menyesuaikan diri dengan lingkungan sekitarnya.

\section{Kesimpulan}

Subjek "aku" tidak hanya menjadi pengamat, tetapi juga bereaksi terhadap apa yang dilihatnya selama perjalanannya. "Aku" juga sebagai subjek atau diri yang terbuka karena dengan mudah mengakrabkan diri dengan subjek lain yang baru dikenalnya. Tidak hanya mengalami perjalanan literal, tetapi juga perjalanan batin, sehingga meningkatkan nilai spiritual dalam diri "aku". Subjek "aku” bukanlah subjek yang mandiri atau bebas karena pada saat yang lain bersubstitusi menjadi 
"kami". Untuk itu, sesuai dengan karakteristik yang sudah disebutkan dan menurut penjelasan Thompson sebelumnya, maka subjek atau diri dalam novel Lumbini ini dapat dikatakan sebagai 'diri romantik' atau diri yang terlibat.

\section{Daftar Pustaka}

Budiman, Kris. 2006. Lumbini. Yogyakarta: JALASUTRA.

Faruk. 2007. Belenggu Pasca-Kolonial. Yogyakarta: Pustaka Pelajar.

Said, Edward W. 2010. Orientalisme. Yogyakarta: Pustaka Pelajar.

Thompson, Carl. 2011. Travel Writing. New York: Routledge Taylor and Francis Group.

\section{Sumber Internet}

http://id.thecircumference.org diakses pada 09/01/2015

http://www.welcomenepal.com diakses pada 10/01/2015

\section{Sumber Lain}

*Tulisan tersebut dikutip dari artikel yang ditulis untuk acara diskusi PKKH bulan Desember 2014. 